\title{
Making the Best of It? Human Resource Management Practices in Universities of Azad Jammu \& Kashmir
}

\author{
Shagufta Ashraf \\ Lecturer at Department of Public Administration, Faculty of Administrative Sciences, \\ University of Management Sciences and Information Technology Kotli, Azad Jammu \& \\ Kashmir. \\ E-mail: xhagufta@yahoo.com
}

\begin{abstract}
Dr. Iftikhar Hussain (corresponding author)
Assistant Professor \& Chairman Department of Commerce, Faculty of Commerce, University of Management Sciences and Information Technology Kotli, Azad Jammu \&

Kashmir.

E-mail: iftikhar_raja@live.com
\end{abstract}

\begin{abstract}
Masood Ahmed Malik
Lecturer at Department of Public Administration, Faculty of Administrative Sciences, University of Management Sciences and Information Technology Kotli, Azad Jammu \&

Kashmir.

E-mail: mrmasoodamalik@gmail.com
\end{abstract}

Doi:10.5296/ijhrs.v4i4.6163ＵRL: http://dx.doi.org/10.5296/ijhrs.v4i4.6163

\begin{abstract}
Pakistan is one of those developing countries, whose literacy rate is very low. It is in a dire need of providing high quality educational facilities to the university students. In today's competitive world, highly educated and technical human resources are required to manage and operate developmental infrastructure. It is only possible through universities having high educational standards and faculty members with strong organizational commitment. The aim of the current study is to find out that, is there a significant relationship between HRM practices implemented and the ranking of universities and to compare HRM practices namely, job definition, training and development, compensation, team work, employee participation, performance appraisal and Promotion Practices in AJKU and MIU of Azad Kashmir. The data were collected through questionnaire comprising of 38 items namely job definition, training, compensation, team work, employee participation, promotion practices and performance appraisal. Overall sample was 44, Overall sample was comprised of 44 executives (Directors/Heads of Departments) selected randomly from AJKU and MIU of Azad Jammu and Kashmir. Collected data were analyzed by applying descriptive and inferential statistical techniques.
\end{abstract}

Key words: HRM, Public Sector, Private Sector, Training, Compensation. 


\section{Introduction}

Education is most powerful tool in the development of personality and human skills, for progressing any nation (whether developed, developing or under developing nations). It gives the proper direction to the attitude and behavior of individuals.

Education is full fledge comprehensive process that dictates people, towards their better survival and rapid growth in this world. Today the whole world is called a global village that leads to more competition. New things have been innovated and discovering every day. To make changes in the society and for the future challenges, there is only one tool which is most important and that is called Education (Shami, 1999).

Today, higher education plays an important role in the development of the economy of a nation. So universities are the only institutions which have intensive human capitals. So in this regard universities are helpful for hiring and managing competitive and skilled teachers. According to the ranking survey given on the website of top universities, not a single university of Pakistan falls into the world's top 500 universities. The reason for this is scarce financial resources, lacking of research environment, fake human resource management (HRM) practices, unproductive yearly policies, lacking of qualified staff and lack of staff training. This study is concerned with HRM practices. There is also lacking in knowledge and research about HRM practices especially at higher level in education sector. So there was a need to review HRM practices at university level. For this reason researcher selected the HRM practices basically to investigate HRM practices in Mohi-ud-din Islamic University (MIU) and Azad Jammu and Kashmir University (AJKU) of Azad Jammu and Kashmir. The purpose behind the research is to give suggestions for the improvement of higher education in $\mathrm{AJ} \& \mathrm{~K}$.

HR is considered as the top most important source for the successful organizations, whereas it is also a source through which organizations can achieve competitive edge. Management of $\mathrm{HR}$ is the most challenging as compared to managing technology or the financial matters. Successful organizations needs effective HRM in a system and should be supported by healthy HRM practices.

Authors argued that people are used as competitive advantage. They focus on the proper utilization of human resources in organizations for business growth(Nyambegera, 2002; Pfeffer, 1994; Poole \& Jenkins 1996) argue is that the organization performance is depending on the effective utilization of the HR and physical assets (Reich, 1991).Material and technological resources got too much importance. This can be achieved by creativeness and innovation of the employees (Nyambegera, 2002). The HR importance cannot be ignored and overlooked in the management of people to achieve the organizational goals.

Pakistan is one among those developing nations where literacy rate is very low. It has a dire need of providing high quality educational facilities to the university students. In today's competitive world, high educated and technical human resources are required to manage and operate developmental infrastructure. It is only possible through universities having high educational standards and faculty members with strong organizational commitment.

The role of HRM practices starts when people are appointed by the organizations or institutes. Therefore employing new workforce in the organization entails the execution of HRM 
practices, these practices specifically include recruitment, selection and hiring of the people. Once workforce is hired then they need to incorporated and familiar with the company's framework through training and socializing. The next stage of the process is to appraise the improvement in employees and motivating them through rewards are also the vital components of HRM (Schuler \& MacMillian, 1984). The comprehensive process of selection, training, appraising, compensating, and communicating is called HRM. Effective workforces can rebuttal challenges that organizations face. (HR) factors such as planning, recruitment, assortment, orientation, education, development, employees' interaction, job investigation, compensation and also overall performance value determination (Dessler, 2007). Planning, recruitment, assortment, education, development, compensation, college employee and their overall performance value determination were preferred and also involved through the Society of HRM of Pakistan (Yeganeh \& Su, 2008). Conceptual approach of HRM is employed with regard to obtaining, developing, encouraging, managing and also getting the employee's dedication and also organization's crucial practices (Ahmed, 1999). HRM principle is known as through a few since the employees' administration and also educational institutions employees' interaction and also through a few as a possible approach with regard to employees' administration integration of corporation tactic (Storey, 1995). These HRM practices usually are favorably related with the organizational motivation and the organizational habits (Allen \& Run, 1998; Arnett \& Obert, 1995; Capelli \& Rogovsky, 1998; Dessler, 1999; Pfeffer \& Trembley et al., 1998; Veiga, 1999). As Teseema \& Soeters (2006) discussed seven practices include things like recruitment and also assortment practices, positioning practices, education practices, Practices, advertising practices, grievance method and also pension check or even cultural protection. Huselid (1995) discussed 11 HRM practices inside the study which are employees assortment, overall performance value determination, motivation compensation, job design and style, grievance processes, data discussing, frame of mind review, job administration contribution, recruitment efforts, employees education and also advertising considerations (Shehzad et al., 2008). Compensation, advertising and overall performance appraisal and also understood employees overall performance. Huselid (1995) describes that will through using effecting HRM practices inside corporation can generate the good success inside employees overall performance and can improve organizational lifestyle in a very constructive method (Shehzad et al, 2008).

"After studying literature, researcher comes to know that only one study has been done for evaluating and improving HRM practices at university level in AJ\&K. HRM and employee performance: A case of university teachers of Azad Jammu and Kashmir (AJK) in Pakistan (Ahmad \& Shahzad, 2011)". That is why researcher decided to work on this particular subject.

\subsection{Objectives of the Study}

Followings are the objectives of the study:

- To investigate HRM practices of AJKU.

- To investigate the HRM practices of HRM executives of MIU. 
- To compare HRM practices of AJKU and MIU.

- To find out the best HRM practices being implemented in the universities studied and suggests a model for ensuring effective human resource practices in studied universities.

- Providing remediation for improving quality of higher education in Azad Jammu and Kashmir.

\subsection{Hypotheses of the Study}

H1: There is a significant and positive relationship between HRM practices implemented and the ranking of universities.

H2: There is a difference between HRM practices exercised by AJKU and MIU.

H2a: There is a difference between training practices exercised by AJKU and MIU.

$\mathrm{H} 2 \mathrm{~b}$ : There is a difference between team work practices exercised by AJKU and MIU.

$\mathrm{H} 2 \mathrm{c}$ : There is a difference between performance appraisal practices exercised by AJKU and MIU.

H2d: There is a difference between job definition practices of AJKU and MIU.

H2e: There is a difference between compensation practices of AJKU and MIU.

H2f: There is a difference between employee participation practices of AJKU and MIU.

$\mathrm{H} 2 \mathrm{~g}$ : There is a difference between promotion practices of AJKU and MIU.

\section{Methods and Procedures}

The simple random technique of sampling was used for the distribution of questionnaires. 70 questionnaires were distributed in the two universities of Azad Jammu and Kashmir for collecting the data, out of which 44 questionnaires were received. The targeted population for this study is Directors heads of the departments. The sample is comprised of 44 overall HRM executives who are randomly selected from AJKU and MIU of Azad Jammu and Kashmir. The collected data were interpreted by using inferential and descriptive techniques of statistics techniques. The instrument used to carry out comparative study included comprehensive questionnaire of 38 questions categorized in seven major dimensions including job definition, training and development, compensation, team work, employee participation, performance appraisal and promotion practices. Questionnaires were distributed among the respondents. The internal reliability of the instrument as tested in the previous study is found as 0.80 . Respondents were requested for mark the level of disagreement or agreement for every question on 5-point Likert Scale.The questionnaire was adopted from the paper of Qureshi \& Ramay, (2006) organized same study on impact of HRM practices on employee performance. Apart from this few questions on particularly HRM practices are included from the questionnaire designed by "Feng-Hui Lee \& Tzai-ang Lee" (2007), for investigating relationship between performance and HRM practices. 35 questionnaires were distributed to AJKU out of which 25 questionnaires were received. The 
response rate for AJK University remained 71.4\%. 35 questionnaires were sent to MIU University and 19 questionnaires were received. The response rate for MIU University remained $54.2 \%$.

\subsection{Research Model}

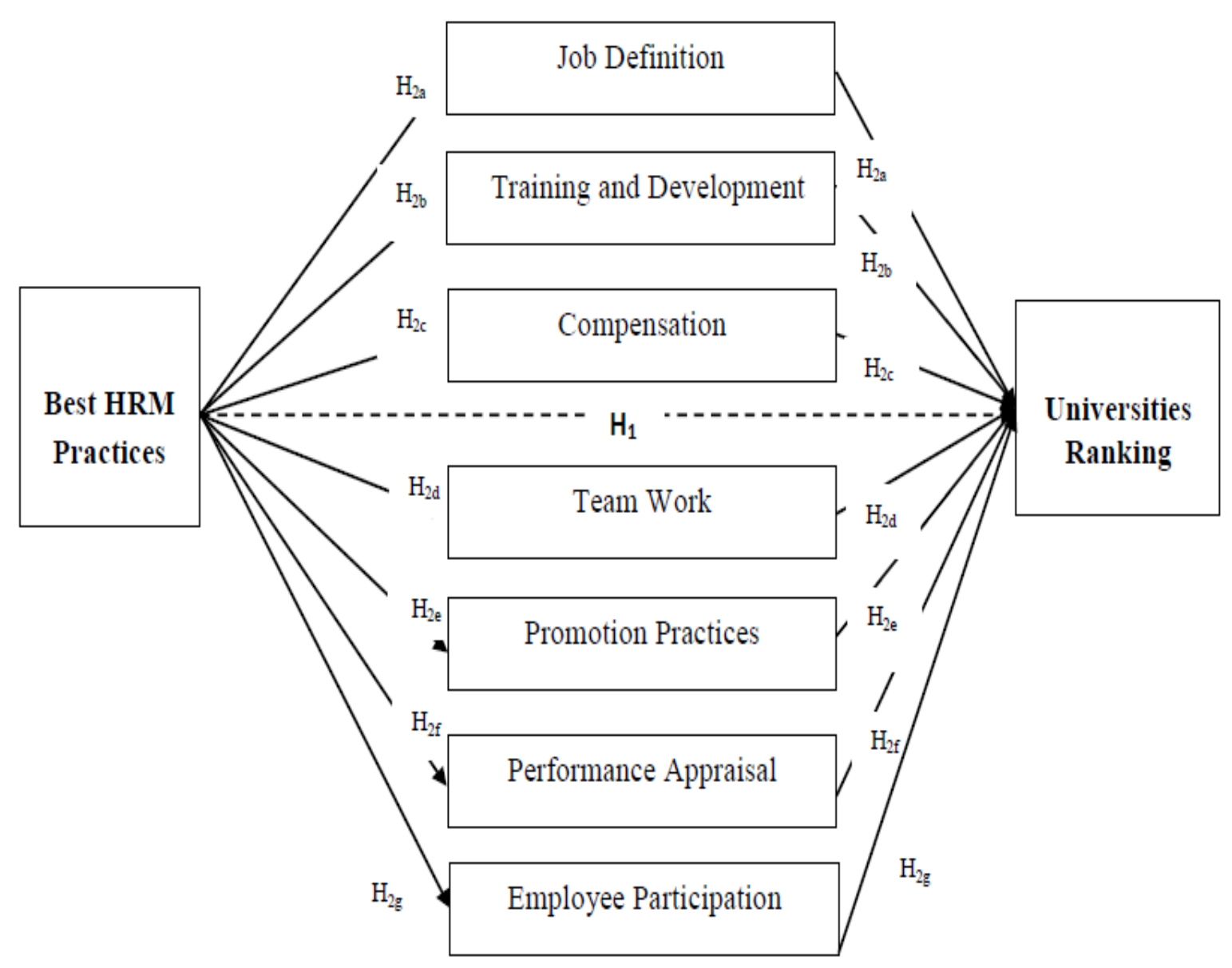

\section{Findings and Discussions}

Data collected through the survey questionnaire were analyzed using Statistical Package for Social Sciences (SPSS).The analysis has been given below according to the hypothesis framed for the study. 
Table 4.1: reliability of different instruments

\begin{tabular}{lcc}
\hline \multicolumn{1}{c}{ Scale } & Cronbach's Alpha & No. of Items \\
Overall Performance & .919 & 2 \\
Training & .801 & 5 \\
Performance Appraisal & .810 & 5 \\
Team Work & .725 & 5 \\
Employee Participation & .709 & 5 \\
Job Definition & .700 & 5 \\
Compensation & .851 & 5 \\
Promotion Practices & .680 & 3 \\
\hline
\end{tabular}

The table 1 indicates the reliability of different instruments used to measure HRM practices in universities of Azad Jammu and Kashmir. Cronbach's Alpha is used to check the reliability. The standard of this Alpha is 0.70. As we see in this table all the instruments are reliable except promotion practices that are near to the standard. The reliability of overall performance is 0.919 , training is 0.801 , performance appraisal is 0.810 , team work 0.725 , employee participation 0.709 , job definition 0.700 , compensation 0.851 and the reliability of promotion practices is 0.680 . The result of reliability test indicates that all the instruments used in the study are reliable.

Table 2: Descriptive Analysis

\begin{tabular}{lccccc}
\hline & $\mathrm{N}$ & Minimum & Maximum & Mean & Std. Deviation \\
\hline Performance & 44 & 1.00 & 5.00 & 3.5455 & .81282 \\
$\begin{array}{l}\text { Training } \\
\text { Performance }\end{array}$ & 44 & 1.00 & 5.00 & 3.2909 & .95426 \\
$\begin{array}{l}\text { Appraisal } \\
\text { Team Work }\end{array}$ & 44 & 1.00 & 5.00 & 3.8455 & .70594 \\
Employee & 44 & 1.00 & 5.00 & 3.7818 & .83172 \\
Participation & 44 & 1.00 & 5.00 & 4.0000 & .70612 \\
Job Definition & 44 & 1.00 & 5.00 & 3.8955 & .71722 \\
Compensation & 44 & 1.00 & 5.00 & 3.9727 & .78780 \\
Promotion Practices & 44 & 1.00 & 5.00 & 3.8864 & .82262 \\
HRM Practices & 44 & 1.00 & 5.00 & 3.8104 & .59843 \\
Valid N (listwise) & 44 & & & & \\
\hline
\end{tabular}


Table 2 indicates the detailed descriptions of instruments used in the research. In this table minimum level and maximum level of agreement and disagreement are indicated at point 1 and 5. Point one indicates the strongly disagreement Reponses from the respondents while the strongly agreed responses are indicated at point five. Mean and standard deviation are also presented in this table. Mean of the variables are towards the agreement. As we see the mean of overall performance is 3.55, training is 3.2909, performance appraisal is 3.8455 , team work 3.78 , employee performance 4 , job definition 3.89 , promotion practices 3.88 , and mean of HRM practices 3.81 .

And the standard deviation of overall performance was 0.81 , it should be less than the half of the mean so it fulfill the requirement of the study, the standard deviation of others; training 0.95 , SD of performance appraisal 0.70 , team work 0.83 , employee participation 0.70 , job definition 0.71 , compensation 0.78 , promotion practices 0.82 , and SD of HRM practices 0.59 the SD of all these variables are less than the half of the mean so these are met with the requirement of the study.

Table 3: Pearson Correlation

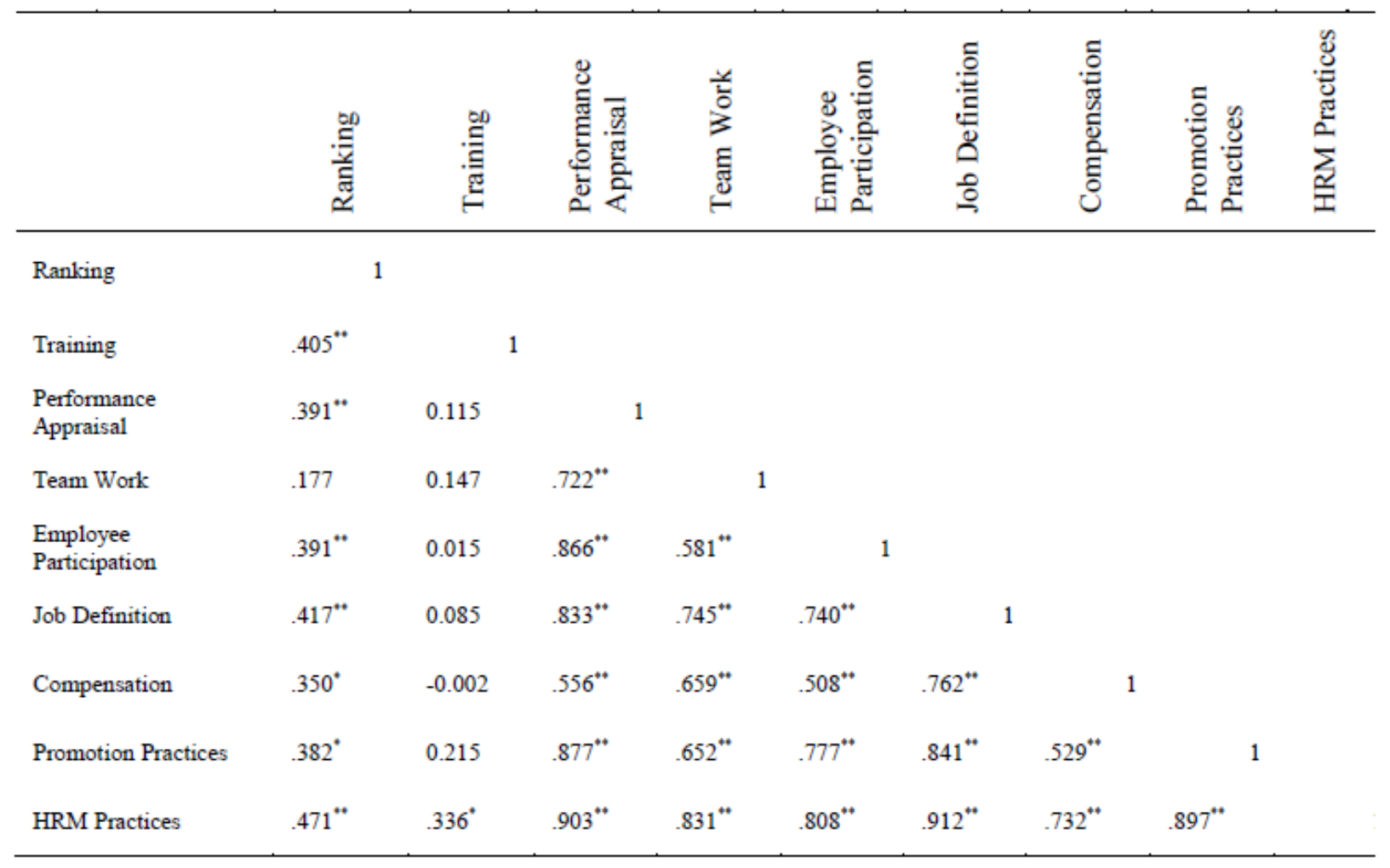

Correlation is used to check the relationship between the variables either relation is positive or negative. Table 3 shows the positive values that indicate that there is positive and significant relationship between the variable of study. When we see the relation of ranking with training it was 0.405 , performance appraisal 0.391 , team work 0.177 , employee participation 0.391 , job definition 0.417 , compensation 0.350 , promotion practices 0.382 and overall HR practices was 0.471 which indicate the overall significant positive relationship, 
the relationship of ranking with teamwork is positive but not significant.

The relationship of training with other HR practices 0.336 , performance appraisal 0.903 , team work 0.831 , employee participation 0.808 , job definition 0.912 , compensation 0.732 and the relationship of promotion practices with overall HR practices are 0.897 which indicated the significant positive relationship between HR practices and other variables.

Table 4: Group Statistics HRM

\begin{tabular}{|c|c|c|c|c|c|c|}
\hline & $\begin{array}{l}\text { Uni=1 for } \mathrm{AJKU}, \mathrm{Uni}=2 \\
\text { for } \mathrm{MIU}\end{array}$ & $\mathrm{N}$ & Mean & Std. Deviation & Std. Error Mean & $\mathrm{T}$ \\
\hline HRM & $\mathrm{A} J \mathrm{KU}$ & 22 & 3.5316 & .68334 & .14569 & 3.462 \\
\hline Practices & MIU & 22 & 2.0892 & .32172 & .06859 & \\
\hline
\end{tabular}

Table 4 shows that the mean score of AJKU is greater than the mean of MIU on the basis of HRM practices. AJKU is much better than MIU due to many factors like better design and structure, which is called the overall infrastructure of AJKU. Table also indicates that the result of the standard deviation of AJKU is greater than MIU. That proves that the overall result of AJKU is more diverse than MIU. Further it shows that t-value-value 3.462 is also greater than critical t-value 1.980 at $5 \%$ level of significance. So the $\mathrm{H} 2$ hypothesis is accepted. This means that there is a difference between HRM practices of AJKU and MIU. Table 5: Group Statistics Training

\begin{tabular}{lcccccc}
\hline & $\begin{array}{l}\text { Uni=1 forAJKU, Uni=2 } \\
\text { for MIU }\end{array}$ & $\mathrm{N}$ & Mean & Std. Deviation & Std. Error Mean & $\mathrm{t}$ \\
\hline \multirow{2}{*}{ Training } & AJKU & 22 & 2.9091 & .90864 & .19372 & 2.869 \\
& $\mathrm{MIU}$ & 22 & 1.6727 & .85645 & .18260 & \\
\hline
\end{tabular}

Table 5 indicates that mean result of AJKU is greater than MIU on the basis of training practices exercised. AJKU is better than MIU due to better training programs which are sponsored by Higher Education Commission. Table also indicates that the mean standard deviation of AJKU is also greater than MIU that shows overall result of AJKU is diverse than MIU. Whereas the result of t-value is 2.869 which is greater than 1.980 at $5 \%$ level of significance. So H2a hypothesis is accepted. This proves that there is difference between training practices implemented by the professional of AJKU and MIU.

Table 6: Group Statistics Performance Appraisal

\begin{tabular}{|c|c|c|c|c|c|c|}
\hline & $\begin{array}{l}\text { Uni }=1 \text { for } A J K U, \text { Uni=2 } \\
\text { for } \mathrm{MIU}\end{array}$ & $\mathrm{N}$ & Mean & Std. Deviation & $\begin{array}{l}\text { Std. Error } \\
\text { Mean }\end{array}$ & $\mathrm{T}$ \\
\hline Performance & AJKU & 22 & 3.5727 & .84919 & .18105 & 2.751 \\
\hline Appraisal & MIU & 22 & 2.1182 & .37877 & .08075 & \\
\hline
\end{tabular}


Table 6 indicates that overall mean of AJKU is greater than that of MIU in the execution of performance appraisal practices. Table also shoes that standard deviation of AJKU is greater than MIU; this means that score of AJKU is widely spread out than MIU. Whereas the value of $t$ is 2.751 which is greater than critical $t$-value that is 1.980 at $5 \%$ level of significance. As a result $\mathrm{H} 2 \mathrm{c}$ hypothesis is accepted. The whole table proves that there is a difference between performance appraisal practices implemented by the professionals of AJKU and MIU.

Table 7: Group Statistics Team Work

\begin{tabular}{|c|c|c|c|c|c|c|}
\hline & $\begin{array}{l}\text { Uni=1 for } A J K U, \\
\text { Uni=2 for } M I U\end{array}$ & $\mathrm{~N}$ & Mean & $\begin{array}{l}\text { Std. } \\
\text { Deviation }\end{array}$ & Std. Error Mean & $\mathrm{T}$ \\
\hline \multirow{2}{*}{ Team Work } & AJKU & 22 & 3.6364 & .90425 & .19279 & 1.165 \\
\hline & MIU & 22 & 3.9273 & .94462 & .15875 & \\
\hline
\end{tabular}

Table 7 indicates that the mean result of MIU is slightly greater than AJKU in their team work practices. Table also shows that the result of standard deviation of MIU is also greater than AJKU. This means that the score of MIU is greater than AJKU. This means that the overall result of MIU is greater than AJKU on their team work practices. Whereas the result of $t$ value is 1.165 that is less than critical $t$ value which is 1.980 at $5 \%$ level of significance. With the help of table $\mathrm{H} 2 \mathrm{~d}$ hypothesis is rejected. It means that there is no difference between team work practices implemented by the HRM professionals of AJKU and MIU.

Table 8: Group Statistics Employee Participation

\begin{tabular}{lcccccc}
\hline & $\begin{array}{l}\text { Uni=1 for AJKU, Uni=2 } \\
\text { for MIU }\end{array}$ & N & Mean & Std. Deviation & $\begin{array}{c}\text { Std. Error } \\
\text { Mean }\end{array}$ & t \\
\hline \multirow{2}{*}{ Employee Participation } & AJKU & 22 & 3.7273 & .86089 & .18354 & 2.751 \\
& MIU & 22 & 2.2727 & .35211 & .07507 & \\
\hline
\end{tabular}

Table 8 indicates that the mean value of AJKU is again greater than that of MIU in their employee participation practices. Table 4.8 indicates that the result of the standard deviation of AJKU is greater than that of MIU. That means that the result of AJKU is more than that of MIU. Whereas the result of $t$ value of AJKU is 2.751 that is greater than that of the critical value which is 1.980 at $5 \%$ level of significance. As a result H2e hypothesis is accepted. This proves that there is a difference between employee participation practices implemented by HRM professionals of AJKU and MIU.

Table 9: Group Statistics Job Definition

\begin{tabular}{ccccccr}
\hline \multicolumn{2}{c}{$\begin{array}{l}\text { Uni=1 for AJU, } \\
\text { Uni=2 for MIU }\end{array}$} & $\mathrm{N}$ & Mean & Std. Deviation & Std. Error Mean & T \\
\hline \multirow{2}{*}{ Job Definition } & AJKU & 22 & 3.6000 & .82808 & .17655 & 2.971 \\
& $\mathrm{MIU}$ & 22 & 2.1909 & .42974 & .09162 & \\
\hline
\end{tabular}


Table 9 indicates that the mean result of AJKU is greater than that of MIU in their job definition practices. Table also shows that the result of the standard deviation of AJKU is greater than the results of the standard deviation of MIU. This means that the result of AJKU is more than that of MIU. Whereas the result of $\mathrm{t}$-value is 2.791 which is greater than 1.980 the critical value at $5 \%$ level of significance. Therefore $\mathrm{H} 2 \mathrm{f}$ hypothesis is accepted. This means that there is a difference between job definition practices implemented by HRM professionals of AJKU and MIU.

Table 10: Group Statistics Compensation

\begin{tabular}{lcccccc}
\hline & $\begin{array}{l}\text { Uni=1 for AJKU, Uni=2 } \\
\text { for MIU }\end{array}$ & $\mathrm{N}$ & Mean & $\begin{array}{c}\text { Std. } \\
\text { Deviation }\end{array}$ & $\begin{array}{c}\text { Std. Error } \\
\text { Mean }\end{array}$ & $\mathrm{t}$ \\
\hline \multirow{3}{*}{ Compensation } & AJKU & 22 & 3.7000 & .99283 & .21167 & \\
& MIU & 22 & 2.2455 & .35953 & .07665 & 2.423 \\
\hline
\end{tabular}

Table 10 indicates that the mean result of AJKU is greater than that of MIU in their particular compensation practices. Table also indicates that the result of standard deviation of AJKU is also greater than that of MIU. This means that the result of AJKU is more than that of MIU. Whereas the result of $t$ value is 2.423 , that is greater than that of the $t$ value which is 1.980 at $5 \%$ level of significance. Therefore $\mathrm{H} 2 \mathrm{~g}$ hypothesis is accepted. This means that there is a difference between the compensation practices implemented by HRM professional of AJKU and MIU.

Table 11: Group Statistics Promotional Practices

\begin{tabular}{|c|c|c|c|c|c|c|}
\hline & $\begin{array}{l}\text { Uni=1 for } A J K U, \text { Uni=2 } \\
\text { for } \mathrm{MIU}\end{array}$ & $\mathrm{N}$ & Mean & $\begin{array}{c}\text { Std. } \\
\text { Deviation }\end{array}$ & Std. Error Mean & $\mathrm{t}$ \\
\hline & & & & & & 2.678 \\
\hline Promotion & AJKU & 22 & 3.5758 & .95497 & .20360 & \\
\hline \multicolumn{7}{|l|}{ Practices } \\
\hline & MाU & 22 & 2.1970 & .52108 & .11109 & \\
\hline
\end{tabular}

Table 11 indicates that overall result of AJKU is greater than that of MIU in their promotion practices as well. Table also indicates that the standard deviation of AJKU is greater than that of MIU. That shows that result of AJKU is more than that of MIU. Whereas the result of tvalue is 2.678 , which is greater than that of the value 1.980 that is the critical e-value 1.980 at $5 \%$ level of significance. Therefore $\mathrm{H} 2 \mathrm{~h}$ hypothesis is accepted. This means that there is a difference between promotion practices implemented by the HRM professional of AJKU and MIU. 


\section{Al Macrothink \\ International Journal of Human Resource Studies \\ ISSN 2162-3058 \\ 2014, Vol. 4, No. 4}

\section{Conclusions and Recommendations}

The conclusions extracted from the above discussions are:

Correlation results indicate the positive values that indicate that there is positive and significant relationship between the HRM practices and the ranking of universities. HRM practices of AJKU are comparatively better than MIU. AJKU is better in the training practices implementation then MIU. MIU is performing better in the comparison of AJKU in the implementation of team work. The reason behind that are effective HRM practices. AJKU is better performing than MIU in their performance appraisal practices. AJKU is performing better than MIU in their employee participation practices. Effective HRM practices are the reason behind better implementation of such practices. AJKU is better performing MIU in compensation practices. The reason is again good HRM practices. AJKU is performing better than MIU in their promotion practices and the reason is good HRM practices.

These practices are considered to be very effective in retaining the valuable human capital. Recommendations are as under:

- $\quad$ MIU should concentrate more on job definition practices if they want to improve their education standard.

- $\quad$ MIU should more focus on employee participation practices if they want to improve their education standard.

- $\quad$ MIU should more concentrate on compensation practices if they want o improve the quality education.

- MIU should give more concentration on training practices if they want to improve the quality education.

- $\quad$ MIU should more concentrate on performance appraisal practices if they want to improve their standard of education.

- MIU should more emphasize on promotion practices if they want to improve their standard of higher education.

- AJKU should more concentrate on team work practices, if they want to enhance their standard of higher education in AJK.

\section{Future Research}

Present study is only concerned with two leading Universities of Azad Jammu and Kashmir .The present study suggests for conducting further research by taking all universities of Azad Jammu and Kashmir. The future researcher can extend this study to compare universities of AJK with other recognized universities of Pakistan. The study also suggests including more variables in this study to make it more comprehensive. Current study opens the avenues for researchers to include more universities and more recognized successful HRM practices for comprehensive results.

\section{References}

Ahmad, S., \& Schroeder, R. G. (2003). The Impact of Human Resource Management Practices on Operational Performance: Recognizing Country And Industry Differences. Journal of Operations Management, 21 (1), 19. Http://Dx.Doi.Org/10.1016/S0272 $\underline{-6963(02) 00056-6}$ 
Tremablay, M. (1998). Influence of HRP on the Mobilization of Blue Collar Workers

Proceedings of Meetings of Association. International De Psychologies De Langue

Francaise, 97-110.

Yeganeh, H. and Su, Z. (2008). An Examination of HRM Practices in Iranian Public Sector.

Personnel Review, 37(2), 203-221.

Arnett, K.P and Obert, T.L. (1995). What is Employee's Really Want Defamation, 41(5), 84.

Aswathappa, K. (2008). Human Resource Management, The Mcgraw Hill Publications, New Delhi.

Storey, J. (1995). Is Human Resource Management on A Critical Text, Journal of Manpower, 16(4), 3-12.

Huselid, M.A.(1995), “The Impact of Human Resource Management Practices on Turnover, Productivity and Corporate Financial Performance. Academy of Management Journal, 38,635-672,Http://Dx.Doi.Org/10.2307/256741.

Khurram Shehzad, S. Bashir, and M. I. Ramay (2008), "Impact of HR Practices on Perceived Performance Of University Teachers In Pakistan", International Review of Business Research Papers, Vol.4 (2), Pp.302-315.

Muhammad Zafar Iqbal., M.I.Arif and F. Abbas, (2011), "HRM Practices In Public and Private Universities of Pakistan", Journal of International Education Studies, Vol.4 (4), Http.//Dx.Doi.Org/10.5539/Ies.V4n4p215.

Shahzad, K., Bashir, S., \& Ramay, M. I. (2008). Impact of HR Practices on Perceived Performance of University Teachers in Pakistan. International Review of Business Research Papers, 4(2), 302-315.

Tessema, M., \& Soeters, J. (2006). Challenges and Prospects of HRM in Developing Countries: Testing the HRM-Performance Link in Eritrean Civil Service. International Journal of Human Resource Management, 17(1), 86-105.

Truss, C. (2001). Complexities and Controversies in Linking HRM with Organizational Outcomes, Journal of Management Studies, 38(8), 1121-1149.

Pfeffer, J. (1995). Producing Sustainable Competitive Advantage through the Effective Management of People. Academy of Management Executive, 9, 55-69. Http://Dx.Doi.Org/10.5465/AME.1995.9503133495

Pfeffer, J. (1998). Seven Practices of Successful Organizations. California Management Review, 40 (2), 96-124

Qureshi, M. T., \& Ramay, I. M. (2006). Impact of Human Resource Management Practices on

Organizational Performance in Pakistan. Muhammad Ali Jinnah University Islamabad.

Patterson Et Al. (1997). HRM Practices, Employee and Organizational Performance: A

Critique of The Research and Guest's Model. [Online] Available: Http://Www.Cheshire.Mmu.Ac.Uk/Bms/Home/Research/Pdf-Doc/Doc-05.Pdf

(November 24, 2004); [Online] Available: Http://Www.Topuniversities.Com/ World-University-Rankings (December 27, 2009)

Schuler, R., \& Macmillan, I. (1984). Gaining Competitive Advantage through Human Resource Management Practices. Human Resource Management, 23(3), 241-255. Http://Dx.Doi.Org/10.1002/Hrm.3930230304 Sels, L. W. Et Al. (2006). Unraveling The HRM 


\section{Macrothink

-Performance Link: Value -Creating And Cost-Increasing Effects Of Small Business HRM. Journal Of Management Studies, 43(2), 319-342. Http://Dx.Doi.Org/10.1111/J.1467-6486. 2006.00592.X

Shami, P. A. (1999). Higher Education In Pakistan: A Cause For Change From Higher Education Commission Review 1. 